\title{
Stroke-ellátást támogató teleradiológiai hálózat a Nyugat- és Dél-Dunántúlon
}

\author{
Bogner Péter dr. ${ }^{1,2}$ - Chadaide Zoltán dr. ${ }^{3}$ - Lenzsér Gábor dr. ${ }^{4}$ \\ Kondákor István $\mathrm{dr}^{5}{ }^{5}$ - Tárkányi Gábor $\mathrm{dr}^{6}{ }^{6}$ - Szukits Sándor $\mathrm{dr} .{ }^{1}$ \\ Juhász Eszter ${ }^{2}$ - Sebestyén Andor dr. ${ }^{7}$ - Janszky József dr. ${ }^{6}$ \\ Büki András dr. ${ }^{4}$ - Dóczi Tamás dr. ${ }^{8}$ - Szapáry László dr. ${ }^{6}$
}

\author{
${ }^{1}$ Pécsi Tudományegyetem, Általános Orvostudományi Kar, Klinikai Központ, Orvosi Képalkotó Klinika, Pécs \\ ${ }^{2}$ ICONOMIX Kft., Pécs \\ ${ }^{3}$ Brainomix Ltd., Oxford, Egyesült Királyság \\ ${ }^{4}$ Pécsi Tudományegyetem, Általános Orvostudományi Kar, Klinikai Központ, Idegsebészeti Klinika, Pécs \\ ${ }^{5}$ Tolna Megyei Balassa János Kórház és Egyetemi Oktatókórház, Neurológiai Osztály, Szekszárd \\ ${ }^{6}$ Pécsi Tudományegyetem, Általános Orvostudományi Kar, Klinikai Központ, Neurológiai Klinika, Pécs \\ ${ }^{7}$ Pécsi Tudományegyetem, Klinikai Központ, Pécs \\ ${ }^{8}$ Pécsi Diagnosztikai Központ, Pécs
}

Bevezetés: A stroke kezelésének lehetőségei az utóbbi években jelentősen megváltoztak: a thrombolysis után bevezetésre került a mechanikus thrombectomia, és a terápiás időablak is jelentősen kitágult az utóbbi évek nagy multicentrikus tanulmányai alapján. Ezek a lehetőségek új igényeket fogalmaztak meg a képalkotó diagnosztikával szemben: az ischaemia okozta morfológiai elváltozások mellett az artériás és a kollaterális rendszer állapotát, valamint bizonyos esetekben az agy szöveti perfúzióját is szükséges meghatározni. Ezeket a komplex kiértékelési feladatokat ma már mesterségesintelligencia-algoritmusok támogathatják, melyek a kiértékelést pár perc alatt elvégezve segítenek a terápiás döntés kialakításában.

Célkitüzés: A Dél- és a Nyugat-dunántúli régióban hat intézmény részvételével egy dedikált stroke teleradiológiai hálózat kialakítása.

Módszer: A stroke-CT-kiértékelő szoftver és a képkommunikáció integrációja, a vizsgálati protokollok technikai paramétereinek egységesítése, a kiértékelési eredmények teleradiológiai megjelenítése valósult meg a hálózat kialakítása során.

Eredmények: A hálózat egységesítette nemcsak a stroke-CT-protokollok beállításait, de beutalási és értékelési szempontjait is. A stroke-CT-kiértékelések és a mechanikus thrombectomiák száma is emelkedett az elmúlt egy évben. Következtetés: A dedikált teleradiológiai stroke-hálózat segítségével optimalizálni kívánjuk a régió stroke-ellátását: egyrészt lehetőleg ne maradjanak ellátatlanul a thrombectomiából valószínúleg profitáló betegek, másrészt ne terheljük az ellátórendszert olyan esetekkel, melyekről a teljes dokumentáció ismeretében derül ki, hogy nem javasolt a beavatkozás.

Orv Hetil. 2021; 162(17): 668-675.

Kulcsszavak: stroke, komputertomográfia, ASPECTS, teleradiológia, mesterséges intelligencia

\section{Teleradiology-based stroke network in Western and Southern Transdanubia in Hungary}

Introduction: The possibilities of cerebral stroke management have changed substantially during the last few years. Following a few multicentric studies, mechanical thrombectomy became an established method besides thrombolysis. In addition, the therapeutic window for both methods is much wider now than before. These changes described above demanded more information of CT morphological changes due to ischemia, but the condition and functionality of the arterial and collateral system, and occasionally tissue perfusion performance should also be characterized. Recently, evaluation of different computer tomographic (CT) measurements can be done using artificial intelligence based methods, which perform data analysis in a few minutes.

Objective: To establish a dedicated stroke teleradiology network with artificial intelligence based image analysis in Western and Southern Transdanubia in Hungary that involves six partner institutes. 
Method: Integration of automated image analysis with teleradiology software was established, and the technical parameters of examination protocols were unified. Results of stroke CT image analysis became accessible through the teleradiology network.

Results: The daily use of integrated central image analysis and image communication had a positive impact on referrals and therapeutic evaluation of stroke cases. The number of image processing and mechanical thrombectomy increased during the last year.

Conclusion: With the help of the dedicated teleradiology stroke network, we want to optimize the stroke care in the region: on the one hand, patients who are likely to benefit from thrombectomy should not be left unattended, on the other, the health care system should not be burdened with cases, when intervention is not recommended having the complete clinical data accessed.

Keywords: stroke, computer tomography, ASPECTS, teleradiology, artificial intelligence

Bogner P, Chadaide Z, Lenzsér G, Kondákor I, Tárkányi G, Szukits S, Juhász E, Sebestyén A, Janszky J, Büki A, Dóczi T, Szapáry L. [Teleradiology-based stroke network in Western and Southern Transdanubia in Hungary]. Orv Hetil. 2021; 162(17): 668-675.

(Beérkezett: 2020. október 28.; elfogadva: 2020. november 24.)

\section{Rövidítések}

ASPECTS $=($ Alberta Stroke Programme Early CT Score $)$ Alberta Stroke Program korai CT-mutató; COVID-19 = (coronavirus disease 2019) koronavírus-betegség 2019; CT = (computed tomography) komputertomográfia; CTA = CT-angiográfia; $\mathrm{CTP}=\mathrm{CT}$-perfúzió; $\mathrm{DICOM}=($ digital imaging and communications in medicine) digitális képalkotás és kommunikáció az orvostudományban; e-CTA = a CTA-értékelést végzó szoftvermodul; e-CTP = a CTP-értékelést végző szoftvermodul; MIP = Maximum Intensity Projection; MR = (magnetic resonance) mágneses rezonancia; PACS $=$ (picture archiving communication system) képarchiváló és kommunikációs rendszer

A fejlett országokban az akut stroke a halálozás és a tartós rokkantság egyik vezető oka, Magyarországon évente körülbelül 25000 akut stroke-esettel számolhatunk. Az esetek mintegy 85\%-ában agyi érelzáródás alakul ki, és ennek következtében lép fel agykárosodás - ezt ischaemiás stroke-nak nevezik. Ebben a stroke-típusban az oki kezelést az elzáródott ér újbóli megnyitása (rekanalizáció) jelentheti $[1,2]$.

Az 1995-ben közölt NINDS-2-vizsgálat igazolta elsőként, hogy a tünetek kialakulásától számított 3 órán belül alteplázzal (rekombináns szöveti plazminogénaktivátor) végzett intravénás thrombolyticus kezelés sikeresen javítja az akut ischaemiás stroke hosszú távú kimenetelét, és csökkenti a mortalitást [3]. A viszonylag szúk, 3 órás időablakon belül azonban csak az akut ischaemiás stroke-ban szenvedő betegek nagyon kis hányadában sikerült megkezdeni a thrombolysist, ezért több alkalommal is történtek próbálkozások az időablak bővítésére. 2008-ban publikálták az ECASS-3- és a SITS-ISTR-vizsgálat eredményeit, amelyek igazolták, hogy megfelelően kiválasztott betegek esetén a tünetek kialakulásától számított 4,5 órán belül is biztonsággal végezhető thrombolysis $[4,5]$. Ezzel szemben a 2012-ben publikált IST-3-vizsgálat rámutatott arra, hogy a 4,5 órán túl alkalmazott thrombolysis esetén a beavatkozás kockázata (intracranialis vérzéses szövődmények kialakulása) már meghaladja annak várható hasznosságát [6].

A thrombolysis fejlődésével és elterjedésével párhuzamosan felmerült az intervenciós, intraarterialis vérrögeltávolítás (thrombectomia) végzésének lehetősége is az akut ischaemiás stroke kezelésére. A kezdeti próbálkozások azonban nem bizonyultak sikeresnek, aminek fó okaként a thrombectomiás eszközök és a képalkotó módszerek fejletlenségét és a célpopuláció nem jól történt meghatározását jelölték meg. Ezek fejlődése eredményezhette, hogy 2014-ben és 2015-ben több nagy klinikai vizsgálat (MR CLEAN, ESCAPE, SWIFT PRIME, EXTEND-IA és REVASCAT) is igazolni tudta az újgenerációs thrombectomiás eszközökkel végzett thrombectomia létjogosultságát. Ezzel a módszerrel elsősorban az elülső Willis-köri proximalis érelzáródások (nagyérocclusio) kezelése lehetséges, amelyeknél a thrombolysis önmagában csak mérsékelten eredményes [7-12].

Az eddig említett vizsgálatok fóleg a tünetek kialakulásától eltelt időt (időablakot) vették figyelembe a kezelések indikációjakor. Fontos paradigmaváltást jelentett azonban, hogy a képalkotó vizsgálatok fejlődésével lehetôvé vált a definitív ischaemiás károsodás (core) és a veszélyeztetett, de korai rekanalizációval még potenciálisan megmenthető agyterület (penumbra) méretének pontos becslése. Az elmúlt néhány évben több vizsgálat is a megfelelő core-penumbra arány alapján végzett rekanalizáció lehetőségét vizsgálta [13]. A 2018-ban közölt DEFUSE 3- és DAWN-vizsgálatban CT-perfúzió (CTP) alapján becsült core-penumbra arány alapján sikerrel végeztek thrombectomiát akár 24 órával a tünetek kialakulását követően [14, 15]. Ugyancsak 2018-ban publikálták a WAKE-UP-vizsgálatot, amelyben MR-vizsgálat alapján végeztek thrombolysist olyan betegekben, akik- 
nél nem volt ismert a tünetek kezdetének ideje [16]. 2019-ben ismertették az EXTEND-IA-vizsgálat eredményeit, melyek elsóként igazolták, hogy a core-penumbra arány CTP-alapú becslését követően akár 9 órán belül sikeresen végezhető thrombolysis [17].

\section{Célkitüzés}

A fenti adatok rámutatnak, hogy az időablak-alapú betegkiválasztást egyre inkább felváltja a betegek specifikusan meghatározott megmenthető agyterületmérete alapján végzett thrombolysis és thrombectomia módszere. Ezek alapján kijelenthető, hogy az akut stroke ellátása jelenleg gyakorlatilag személyre szabottan történik. Ennek alapja a gyors és hatékony képalkotó diagnosztika, melynek eredménye a kezelőorvos részére hozzáférhetô kell, hogy legyen időbeli és térbeli korlátok nélkül. Jelen munkánkban bemutatjuk ennek megvalósulását és müködését a Pécsi Stroke Centrumban.

\section{Módszerek}

\section{Képalkotó diagnosztika}

A terápiás lehetőségek bővülésével a képalkotó diagnosztika feladata is megváltozott. Korábban a vérzéses és az ischaemiás stroke elkülönítése volt az elsődleges cél, de manapság az ischaemiás stroke okozta elváltozások sokkal részletesebb analízise szükséges. Míg korábban strokegyanú esetén elegendő volt egy natív koponya-CT-mérés, manapság ezt kisebb szeletvastagsággal végzik, mely rutinszerúen kiegészül CT-angiográfiával (CTA) az érelzáródás helyének meghatározására, megfelelő indikáció alapján pedig CTP-vizsgálattal a potenciálisan menthető területek azonosítása válik lehetővé. A natív CT-felvételeken az ischaemiát követô parenchymakárosodást értékelni kell, ezt ma már az ASPECTS- (Alberta Stroke Programme Early CT Score) kritériumok szerint végezzük [18]. Az ASPECTS-rendszer az arteria cerebri media ellátási területét 10 részre osztja, melyek l-1 pontot jelentenek. Az egyes területek ischaemiás sérülése 1 pont levonást eredményez. Az ASPECTS-rendszert ma már világszerte alkalmazzák diagnosztikai és prognosztikai céllal, valamint a mechanikus thrombectomia indikációjánál is, mely szerint 6-10 ASPECTS-pontszám esetén a thrombus eltávolítása javasolt.

A CTA-vizsgálat a stroke-protokoll szerint többfázisú mérést jelent, melynek artériás fázisa alkalmas az artériás elzáródás lokalizálására, a későbbi fázisok pedig a kollaterális rendszer megítélését teszik lehetővé. A kollaterális rendszer a kontrasztanyag-telődés időbeli lefolyása alapján jellemezhetô, 1-3 pontszám között (collateral score) [19].

Amennyiben indikált, 6 órán túli stroke-esetekben a CTP-mérés is elvégzésre kerül. Néhány ml-es kontrasztanyagbolust követôen gyakori ismétléssel készülnek a CT-képek a vizsgálandó területről/volumenről, így lehe- tővé válik a kontrasztanyag szöveti perfúziójának az idő függvényében való megjelenítése és a perfúziós görbe elemzésével különböző paraméterek meghatározása. Ezen paraméterek jó pontossággal adják meg a definitív és a potenciálisan menthetô területeket.

A korai ischaemiás CT-jelek kimutatása gyakorlott radiológus számára is lehet kihívás, ezért az ASPECTSrendszer megfelelő alkalmazása is gyakorlatot igényel. Mivel az ASPECTS-rendszernél a vizsgálók közötti egyezés mértéke részben vitatott, ennek standardizálása mindenképp szükségszerü volt [20]. Az elmúlt években fejlesztettek ki olyan mesterségesintelligencia-módszereken alapuló algoritmusokat, melyek a CT-felvételeket az ASPECTS-rendszer szerint rövid idő alatt reprodukálhatóan értékelik, azaz az automatikus régiófelismerés után a denzitáseltéréseket kvantifikálják [21]. Ezek a számítógépes alkalmazások jelentős szerepet kaptak a különböző multicentrikus nemzetközi tanulmányokban, mivel ezek segítségével vált lehetővé a vizsgálatok egységes értékelése [22].

A CTP-s mérés kiértékelése ugyancsak számítógépes program segítségével történik; ennek eredményeképpen az anatómiai régiókban különböző származtatott áramlási paraméterek határozhatók meg, melyek mennyiségileg jellemzik a szöveti perfúziót - ezeket színkódolt térképekkel lehet megjeleníteni.

\section{A betegellátás szempontjai}

A mechanikus thrombectomia neurointervenciós centrumokban történik (jelenleg az országban 6 ilyen múködik), melyek regionális feladatot látnak el, míg a strokegyanús beteg a hazai 39 stroke-centrum valamelyikébe érkezik. Stroke-gyanú esetén a CT-vizsgálat természetesen minden esetben megtörténik, melynek alapján a kezelőorvos felméri a terápiás lehetőségeket. Amennyiben a thrombectomia lehetősége felmerül, úgy szükséges a neurointervenciós szakemberrel történő konzultáció ezt nehezítheti, hogy a CT-felvételeket a neurointervenciós szakember nem tudja megnézni, ugyanakkor a mútéti indikáció e nélkül nem lehetséges. Egy ilyen helyzetben a neurointervenciós szakember a referáló kollégának, valamint a CT-vizsgálatot értékelő radiológusnak a véleményére támaszkodhat, illetve ezek alapján kezdeményezheti a páciens fogadását a thrombectomiás beavatkozásra. Potenciális problémát jelent az is, hogy intézményenként eltérhet a CT-vizsgálati protokoll (a mérések típusa, száma, valamint a technikai beállítások), ami a vizsgálat értékét és értékelését egyenetlenné teszi. Kérdés továbbá a stroke-centrumban elérhetô radiológus tapasztalata, mely a kiértékelés eredményét szintén befolyásolja. Mindazonáltal egyértelmú cél, hogy ne maradjanak ellátatlanul a beavatkozásból valószínúleg profitáló betegek, és ne terheljük az ellátórendszert olyan, részben hiányos információk birtokában átvett esetekkel, melyeknél a teljes dokumentáció ismeretében derül ki, hogy nem javasolt a beavatkozás. 
A fenti szempontok alapján több olyan kritérium fogalmazható meg, mely segíti és egységesíti a stroke-gyanús páciensek CT-vizsgálatának elvégzését és kiértékelését, így a thrombectomia indikációja haladéktalanul felállítható, és a páciens szükséges szállítása is kezdeményezhető: - egységes CT-vizsgálati indikáció - 1. natív CT, 2. natív CT és CTA, 3. natív CT, CTP és CTA;

- egységes CT-mérési protokoll;

- a CT-felvételek objektív, egységes kiértékelése - kiértékelőszoftver alkalmazása;

- gyors képkommunikáció, mely a CT-vizsgálat felvételeit és a kiértékelés eredményét is megtekinthetővé teszi, dedikált teleradiológiai szoftver alkalmazásával.

A Pécsi Tudományegyetem Klinikai Központja Neurológiai Klinikájának Stroke Tanszéke, az Idegsebészeti Klinika, az Orvosi Képalkotó Klinika és a Pécsi Diagnosztikai Központ konzorciális együttmúködésében jött létre egy olyan szakmai és informatikai megoldás, mely a fenti kritériumoknak megfelel, és így a stroke-ellátás hatékonyságát regionálisan javítani tudja.

\section{Képkommunikáció}

Az elmúlt évtizedben a képalkotás digitalizációja hazánkban is gyakorlatilag teljessé vált, ami nemcsak az intézményen belüli (PACS - picture archiving and communication system), hanem az intézmények közötti képkommunikációt (teleradiológia) is lehetővé tette. Számos intézményben alkalmazni kezdték a teleradiológiát, mely dedikált szoftveres megoldást igényel, és fontos ismérve a gyors képkommunikáció, ami egy-egy vizsgálat pár másodperc alatti letöltését jelenti. A gyors adatátvitel azért is szükséges, mert a fent részletezett vizsgálatok betegenként akár 2-3000 képet is eredményezhetnek, ami GB-os fájlméretet jelent. A képkommunikáció fontos aspektusa, hogy a radiológiában kiforrott szabványos képformátumot (DICOM) alkalmaznak, mely egységesíti a képkommunikációs protokollokat és megoldásokat. Ennek köszönhetően a gyártótól függetlenül megjeleníthető a különböző modalitásokon előállított kép akár a kórházi PACS- vagy a teleradiológiában alkalmazott szoftveres környezetben. Természetesen lényegesen hatékonyabb, ha egységes képkommunikációt alkalmazunk, ami a teleradiológia elterjedésének köszönhetően meg is valósult a régióban, azaz az intézmények közti képkommunikáció a régióban az eRAD szoftver (Greenville, SC, Amerikai Egyesült Államok) alkalmazásával történik. Ez a szoftver gyorsan és biztonságos módon közvetíti a képadatokat, kommunikál a kórházi PACS-rendszerekkel, és kontrollált hozzáférést biztosít.
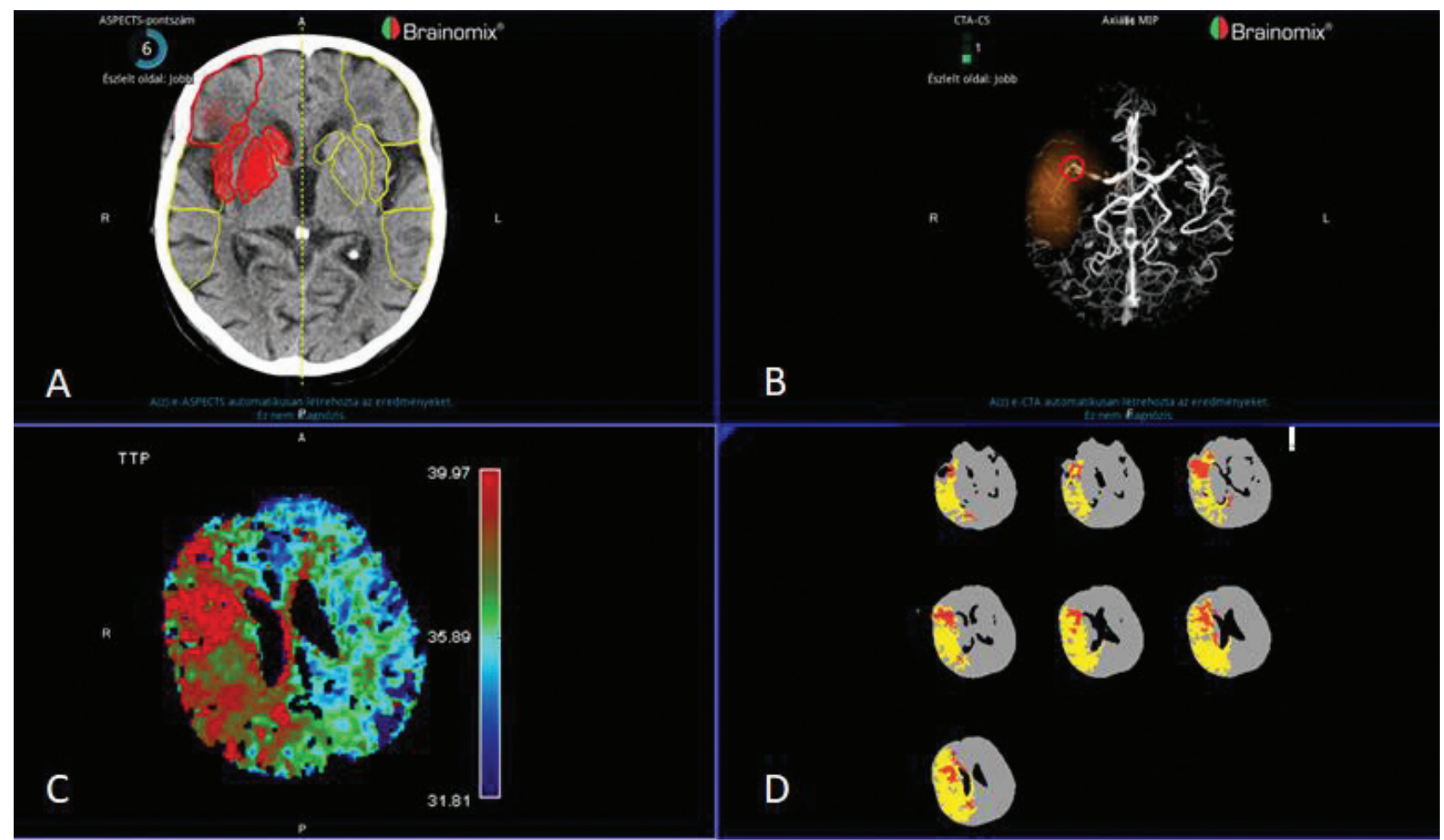

B

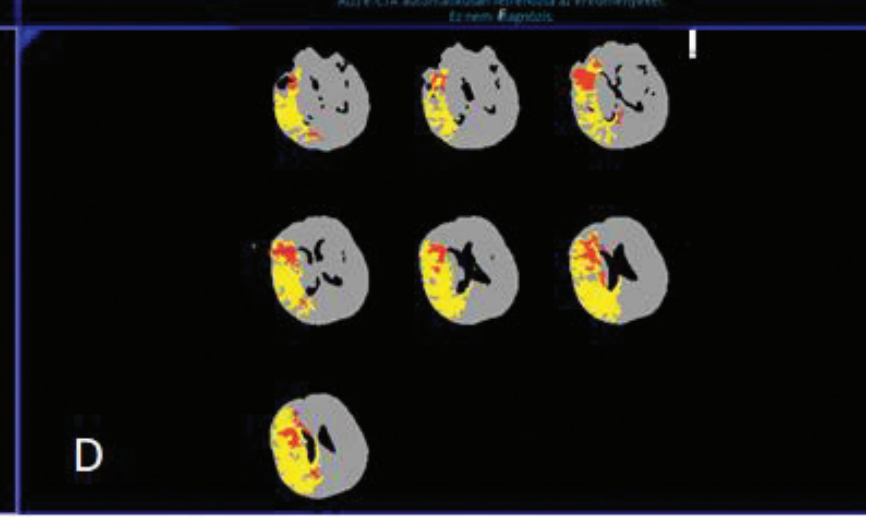

1. ábra
Az e-Stroke Suite szoftver kiértékelése
A) Az ASPECTS-pontszám-területek szegmentálása és az ischaemiás terület színkódolása (piros)
B) A CT-angiográfia MIP-rekonstrukciója és az érelzáródás jelölése
C) „Time-to-peak” perfúziós térkép, mely mutatja a jobb oldali a. cerebri media ellátási területének megfelelő perfúziós hiányt (piros)
D) Ischaemiás core (piros) és penumbra (sárga) perfúziós térkép
ASPECTS $=$ Alberta Stroke Program Early CT Score CT $=$ komputertomográfia $;$ MIP = a legnagyobb intenzitás kivetítése 


\section{Az akut stroke képalkotásának automatizált, szoftveres támogatása-e-Stroke Suite}

A mesterséges intelligencia igen széles gyüitőfogalom, amelyen az emberi intelligencia és mentális feladatok „utánzására” szolgáló számítógépes rendszert értjük. A mesterségesintelligencia-alkalmazások egyre nagyobb teret nyernek a klinikai gyakorlatban. Olyan területeken sikeresek elsősorban, ahol a rutinfeladatok elvégzését tudják automatizálni, pontosítani, illetve felgyorsítani [23]. Az akut stroke ellátása a mesterséges intelligencia egyik ilyen, gyorsan fejlődő alkalmazási területe, ahol az automatizált értékelés a diagnózis pontosságának és a betegellátás minőségének javítását tudja eredményezni $[24,25]$. A stroke-ellátás alapja a CT- (esetleg MR-) vizsgálatok megfelelő elemzése és standardizált értékelése rövid idő alatt, így ennek automatizálása és az eredmények megosztása jelentős javulást eredményez a strokeellátás múködésében $[23,26]$.

Az e-Stroke Suite (1. ábra) mesterségesintelligenciaalgoritmusokat használ, és kombinálja a hagyományos háromdimenziós grafikát, statisztikai módszereket, valamint a gépi tanulás klasszifikációs technikáit. Az algoritmusokat sok ezer felvételt tartalmazó adatbázis felhasználásával tanították, amely mind stroke-os betegek, mind egészséges kontrollok CT-vizsgálatainak széles skáláját tartalmazza, valamint egyéb képalkotó - például a CTtől számított 1-2 órán belül elkészített MR-vizsgálatok alapján nyert volumetriás - adatokat használnak fel a fejlesztő́k az algoritmus tanítása során.

A natív, az angiográfiás és a perfúziós felvételkor nyert DICOM-képeket az algoritmus rekonstruálja és „újraszeleteli" a bemeneti adatok szabványosítása céljából, így kompenzálva a felvételek elkészítésekor az akut felvételeknél gyakori mútermékeket (például a fej rotációja, billenése, a középvonal elmozdulása). Ez biztosítja, hogy a felvételek szabványos referenciakeretben jelenjenek meg, ami megkönnyíti a felvételek helyes értelmezését, és alapot teremt a detektáló algoritmusok megbízható múködéséhez.

Az e-Stroke Suite bemeneti követelményei megfelelnek a klinikai gyakorlatban széles körben használt képalkotási protokolloknak. A natív CT-vizsgálat esetében legfeljebb $2 \mathrm{~mm}$, angiográfiás felvételeknél legfeljebb 1 mm és a perfúziós mérés esetében $2-10 \mathrm{~mm}$ közötti szeletvastagság ideális. Natív felvételek esetén a felvételnek a Willis-kör és a vertex közötti teljes területet, angiográfiás felvételek esetében az aortaívtől a vertexig tartó területet kell leképeznie. A perfúziós mérésnek legalább $8 \mathrm{~cm}$-es vastagságban, az a. cerebri media ellátási területét magában foglalva kell készülnie.

Az e-Stroke Suite szoftvercsomag 3 modult foglal magában. Az e-ASPECTS [21] szegmentálja az a. cerebri media keringési területeket, és illeszti az ASPECTS-régiókat [18]. Megjelöli az ASPECTS-pozitív régiókat, kiszámítja az ASPECTS-pontszámot, és hőtérképen jelzi az akut és nem akut hipodenzitást az a. cerebri media területén, valamint kiszámítja ezek térfogatát.

Az e-CTA szegmentálja az agyi ereket, elemzi az artériás bemeneti és vénás kimeneti értékeket, és ez alapján kiszámítja az angiográfiás fázist (korai, csúcsartériás, egyensúlyi, korai és késői vénás fázis). Amennyiben a felvétel a csúcsartériás vagy az egyensúlyi fázisban készültt, detektálja és vizuálisan megjelöli a nagyérelzáródást az a. carotis interna és a. cerebri media (az Ml és a proximalis M2 magasságában) erekben, valamint elemzi és pontozza a kollaterálisok állapotát (CTA-CS-pontszám) [26]. Multifázisos CTA esetén színkóddal vizualizálja, hogy melyik fázisban volt az adott ér kontraszttartalma a legmagasabb, így nyújtva támpontot a keringés időbeli dinamikájának megértéséhez.

Az e-CTP-modul a perfúziós felvételeket elemzi automatikusan. Számos pont alapján meghatározza az artériás bemeneti és vénás kimeneti görbéket, majd ezeket felhasználva számol és vizualizál perfúziós parametrikus térképeket. Az előre megadott küszöbértékek alapján jelzi a core- és penumbratérfogatot ml-ben, a területek elhelyezkedését és a 'mismatch' arányt [8].

Az eredményeket és a jelölésekkel ellátott képeket a szoftvercsomag a PACS-rendszerben, egy böngészőfelületen és egy okostelefon-applikációban teszi elérhetővé valós időben. A kórházi informatikai határokat nem hagyja el szenzitív betegadat, az eredményeket a rendszer pszeudoanonimizálja. Az eredményeket és a képeket az alkalmazásból más orvosok számára is megoszthatóvá tudja tenni.

\section{Eredmények}

\section{Aze-ASPECTS szoftver teleradiológiai alkalmazása}

Az e-ASPECTS szoftver 2017-ben került a PTE Orvosi Képalkotó Klinikára tesztelés céljából. Ekkor a sürgősségi ellátást végző CT-készüléket és az alkalmazást futtató számítógépet kapcsolták össze, tehát a CT-vizsgálatokat erre a számítógépre kellett átküldeni, a kiértékelés eredményét pedig szintén itt lehetett megtekinteni. Ennek a megoldásnak nyilvánvaló korlátja, hogy csak egy adott CT-készüléken végzett vizsgálatok kiértékelése végezhetô el, a kiértékelés eredménye pedig szintén csak lokálisan érhető el. Regionális centrum lévén egyértelmú volt az igény, hogy a stroke-vizsgálatok kiértékelése, csakúgy, mint azok eredménye regionálisan elérhető legyen, egyben lehetôvé váljon a beküldő fél és a neurointervenciós szakember interaktív konzultációja. Idóközben, a szoftverfejlesztés eredményeként, az ASPECTS-pontszám meghatározásán túl a CTA- és a CTP-mérések kiértékelése is elérhetôvé vált.

A fenti igények és lehetőségek alapján merült fel egy olyan megoldás lehetősége, mely integrálja a teleradiológia és a szoftveres képkiértékelés funkcionalitásait az alábbiak szerint: 


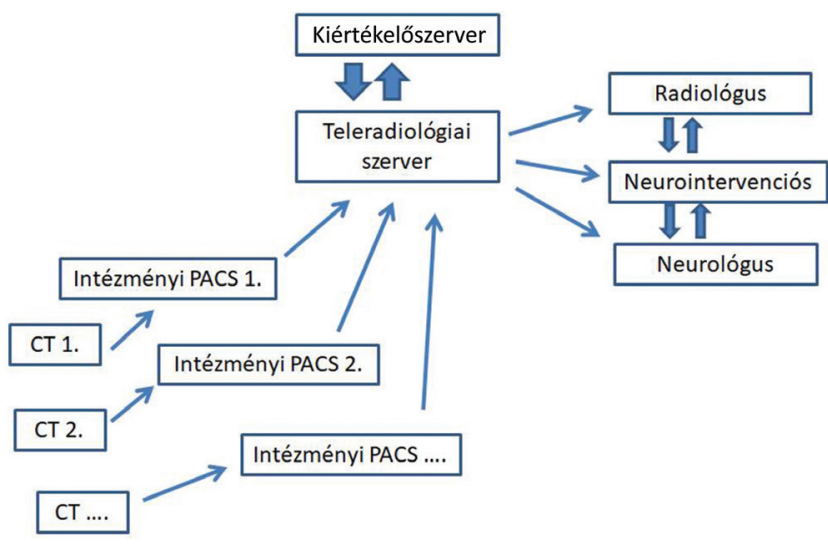

2. ábra

$\mid \begin{aligned} & \text { A teleradiológiai stroke-hálózat felépítése } \\ & \text { CT = komputertomográfia; PACS = képarchiváló és kommuni- } \\ & \text { kációs rendszer }\end{aligned}$

- A stroke-CT-vizsgálatok egységes elérhetőségét egy dedikált teleradiológiai szerver teszi lehetővé, mely egységes platformon fogadni tudja a különböző intézményekben készült vizsgálatok képanyagát. A jogosultságkezelés lehetôséget ad a vizsgálatok adatvédelmi szempontból szabályos megtekintésére. Az egységes elérhetőség nemcsak felhasználókra értendő, hanem a szoftveres kiértékelésre is.

- A vizsgálatok automatikus kiértékeléséhez több feltételnek is teljesülnie kell:

1) a teleradiológiai szerver és a kiértékelőszoftvert futtató számítógép kommunikációja;

2) a különböző CT-mérési sorozatok (natív CT, CTA, CTP) felismerése és szortírozása a célzott elemzések miatt.
- A kiértékelés eredményének egységes elérhetősége a teleradiológiai szerveren lehetséges akkor, ha a kiértékelés eredménye visszakerül az adott páciens képanyagához.

- A részt vevő szakemberek interaktív kommunikációját szintén a teleradiológiai rendszer segíti, mely lehetővé teszi a CT-képek és a vizsgálati eredmények biztonságos megosztását.

Javaslatunkra a fejlesztőcég elkészítette a szoftver hálózati verzióját, mely a fenti kritériumoknak megfelelő funkciókkal rendelkezik (2. ábra). Egy dedikált teleradiológiai szerver üzembe állítása után sikerült a kiértékelőrendszerrel való kapcsolat kiépítése, majd a hálózatban részt vevő intézményi partnerek képkommunikációjának kiépítése. Jelenleg a teleradiológiai stroke-hálózatban Pécs, Szekszárd, Baja, Nagykanizsa, Zalaegerszeg és Szombathely vesz részt.

A 3. ábrán a 2019. szeptember és 2020. október között történt stroke-CT-vizsgálatok képkiértékelésének száma látható az egyes intézmények bontásában, valamint ezeket összesítve. Bár az egyes egészségügyi intézmények bekapcsolódása nem egyszerre történt, látható, hogy egy év alatt a képkiértékelések havi mennyisége a kétszeresére nőtt. A vizsgált intervallumban a pécsi számok folyamatosan mérsékelt emelkedést mutattak, míg Szekszárdon és Zalaegerszegen az előbbinél kevesebb, de egyenletes a kiértékelések havi mennyisége. Nagykanizsán ez év második felétől jelentős számban alkalmazzák a kiértékelőrendszert, míg Baján és Szombathelyen havonta csak 5-10 esetben.

A Pécsi Tudományegyetem Klinikai Központjának Idegsebészeti Klinikáján a 2019. és 2020. évben végzett

\section{0}

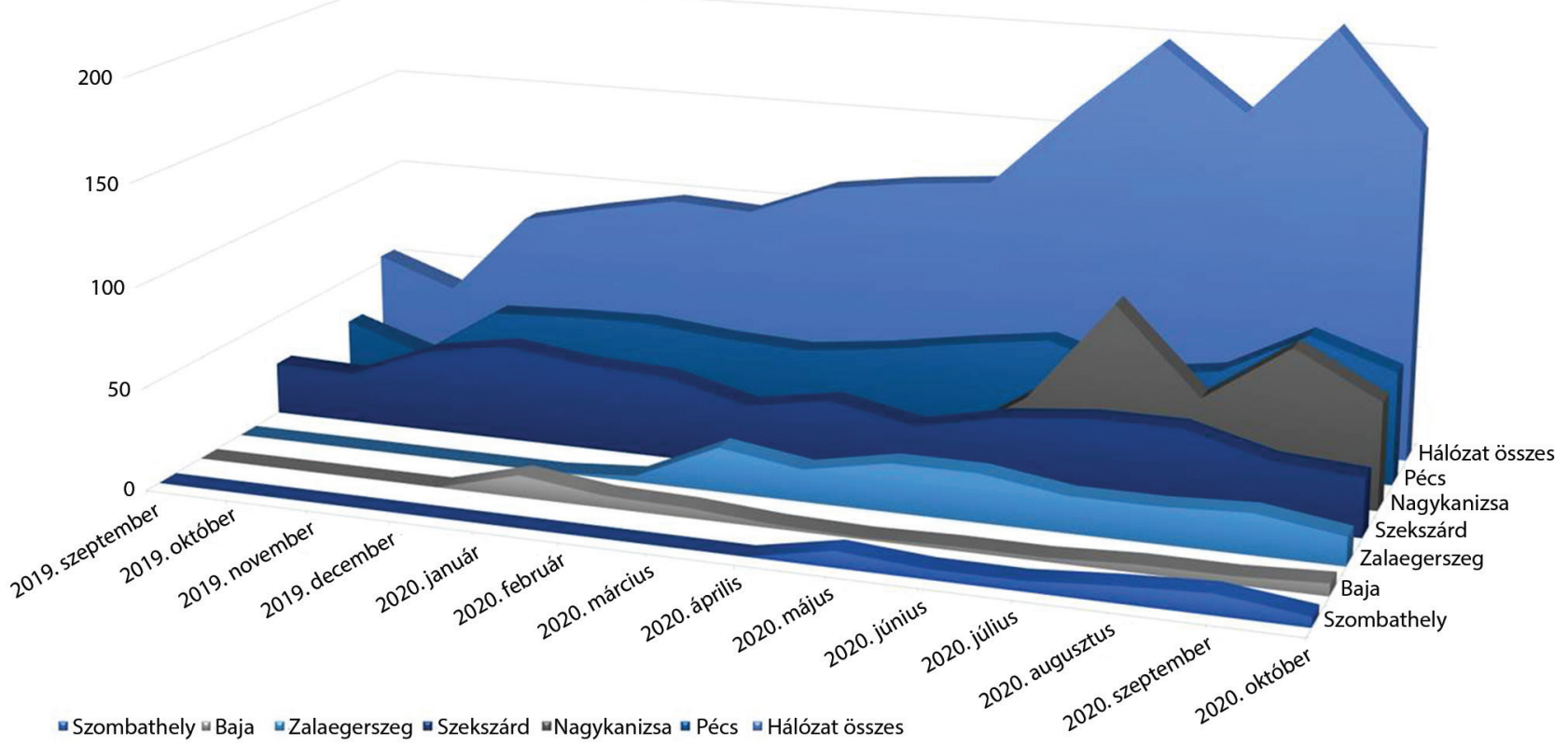

3. ábra $\quad$ A stroke-CT-vizsgálatok képkiértékelésének száma intézményenként és a hálózatban összesen 2019. szeptember és 2020. október között CT = komputertomográfia 


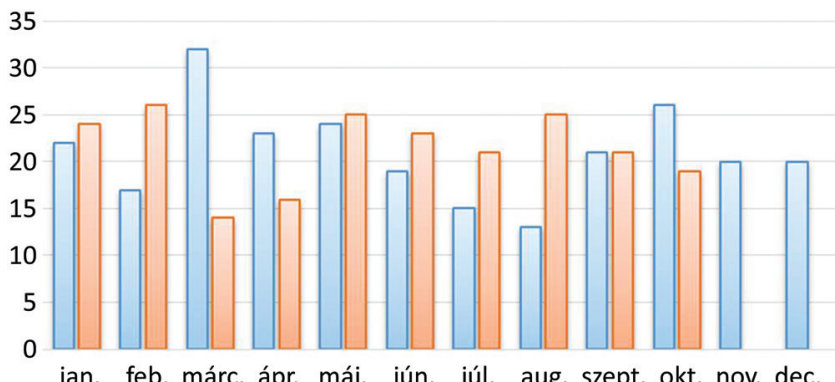

jan. feb. márc. ápr. máj. jún. júl. aug. szept. okt. nov. dec.

$\square 2019 \square 2020$

4. ábra

A Pécsi Tudományegyetem Klinikai Központjának Idegsebészeti Klinikáján elvégzett mechanikus thrombectomiák száma 2019-2020-ban

mechanikus thrombectomiák számát a 4. ábrán tüntettük fel. A beavatkozások számát természetesen számos tényező befolyásolja: a legszembetűnőbb a COVID19-járvány tavaszi és őszi hullámának hatása, ugyanakkor a január-februári és a nyári hónapok adatai egyértelmü emelkedést mutatnak a 2019. évvel összehasonlítva.

\section{Megbeszélés}

\section{A bálózat kialakitásának tapasztalatai}

A stroke-ellátást támogató teleradiológiai hálózat tervét, megvalósítását és fenntartását a PTE Klinikai Központja, a Pécsi Diagnosztikai Központ és az ICONOMIX Kft. támogatta. Az informatikai feladatok megoldásán túl a teleradiológiai hálózat kiépítésében és üzemeltetésében meghatározó szerepet játszott/játszik a projektmenedzser, aki segített definiálni a résztvevőket, a projektet támogató szakmai team tagjait, valamint az ő feladataikat a projekt során. Minden területen - úgymint igazgatás, radiológia, neurológia, informatika - kell legalább egy kompetens kolléga, aki a csatlakozni kívánó intézményt képviseli a rendszer kiépítése során. A projektmenedzser feladata e szereplők transzparens tájékoztatása, a hibák feltárása és a projektépítés fázisainak követése, a folyamatos kapcsolattartás pedig segíti a hálózat üzemeltetését is.

A klinikus kollégák visszajelzései és az üzemeltetés tapasztalatai az alábbiakban foglalhatók össze:

- A releváns képalkotó (koponya-CT, CT-angiográfia) vizsgálati protokollok egységessé és teljes mértékben kompatibilissé váltak a régió többi laboratóriumával, a nap 24 órájában múködő és elérhető stroke-szerver folyamatos lehetőséget ad az akutan elvégzett vizsgálatok teljes képanyagának azonnali, prompt feltöltésére, valamint azok kiértékelésére csakúgy, mint a neurointervenciós kollégával való szinte azonnali konzíliumra.

- A hálózatba bekapcsolt beküldő intézményben készült felvétel pár perc alatt rendelkezésre áll. Ezekből az indikáció felállításához legfontosabb képalkotással nyerhető információk, az ASPECTS-pontszám, az el- záródás ténye, lokalizációja megállapítható, és a betegátvétel szükségessége a többi referált eset adatainak ismeretében felállítható. Kisebb eltérések a gépi és a saját pontozásban lehetnek, és bár általában a saját véleményre hagyatkoznak, kérdéses esetben a szoftver által végzett kiértékelés segítséget jelent, mivel az infarktus korai szakaszában a CT-felvételeken látható eltérések kevésbé szembetűnőek.

- Nagy segítséget jelent a gépi kiértékelés a CTP-vizsgálatok eredményeinek értelmezésében. A perfúziós adatokból a szoftver az infarktust és a hipoperfundált agyállományt meghatározza, ezek térfogatát kiszámolja. Ezek ismeretében a mütét és az átvétel szükségessége eldönthető.

- A kiértékelésre feltöltött összes vizsgálat száma folyamatos emelkedést mutat, 2020. szeptemberben ez több mint 200 vizsgálat volt. Az egyes intézmények által feltöltött vizsgálati szám eltérő, aminek oka további vizsgálat tárgya lehet.

- Megerősödött az együttmúködés a beküldő neurológiai osztályok és a thrombectomiát végző neurointervenciós centrum között. Ennek köszönhetően a beutalási és a terápiás protokollok is jelentős mértékben homogenizálódtak, aminek következtében a thrombectomiás centrum szerepe felértékelődik.

- A hálózat természetesen alkalmas bármilyen - nem stroke miatt készült - vizsgálat fogadására, így azok konzíliuma (neurológiai, idegsebészeti) is egyszerúbbé vált.

A stroke-ellátást támogató teleradiológiai hálózat működésének kezdeti eredményei azt mutatják, hogy a képkiértékelések száma egy év alatt megduplázódott, aminek hátterében az újabb intézmények csatlakozása, valamint a fokozódó képfeldolgozási igény és gyakorlat állhat. További vizsgálatok szükségesek viszont annak feltárására, hogy az egyes intézmények között látható különbségeknek milyen okai vannak - ezek a vizsgálatok egyben segíthetik az egységes szemlélet és gyakorlat kialakítását, ami a régióban a stroke-ellátás minőségét javíthatja. A mechanikus thrombectomiák száma a COVID-19-járvány által nem befolyásolt hónapokban emelkedett 2019-2020 vonatkozásában; ennek hátterében természetesen számos tényező állhat, melyek közül a stroke-ellátást támogató teleradiológiai hálózat lehet az egyik. További részletes elemzés szükséges a fent felsorolt eredmények okainak feltárására, mely segíthet a stroke-betegek ellátásának optimalizálásában, és egyben egészség-gazdaságtani mutatók is nyerhetők. A kiértékelőszoftver lokális konfigurációban múködik hazánkban, 2-3 intézményben, ugyanakkor a fejlesztőcég Európában máshol is sikeresen telepítette a fent bemutatott hálózati megoldást, és szakmai kommunikáció alapján úgy tünik, hogy egy hazai országos hálózat kialakítása is megvalósulhat. A kidolgozott hálózati radiológiai megoldás természetesen más kiértékelőrendszerrel is müködtethető, amire példa a Hunchest-programban (alacsony dózisú CT-tüdőszűrés) üzemelő, szintén mesterséges 
intelligencián alapuló kiértékelőszoftver. A hálózati megoldás nagy előnye, hogy elegendő regionálisan/országosan egy hardver és szoftver telepítése és üzemeltetése, ami a szolgáltatás biztonságát egyértelmúen növeli, a költségeket pedig bizonyosan csökkenti.

Anyagi támogatás: A szerzók anyagi támogatásban nem részesültek.

Szerzői munkamegosztás: A koncepció kidolgozása, a kézirat megírása: B. P., D. T., S. A. Szakmai megvalósítás, hálózati munka, a kézirat megírása: Sz. S., J. E., C. Z. Klinikai tapasztalatok, a kézirat mgírása: Sz. L., T. G., K. I., L. G., J. J., B. A. A cikk végleges változatát valamennyi szerző elolvasta és jóváhagyta.

Érdekeltségek: A szerzőknek nincsenek érdekeltségeik.

\section{Irodalom}

[1] Feigin VL, Roth GA, Naghavi M, et al. Global burden of stroke and risk factors in 188 countries, during 1990-2013: a systematic analysis for the Global Burden of Disease Study 2013. Lancet Neurol. 2016; 15: 913-924.

[2] Donkor ES. Stroke in the 21 st century: a snapshot of the burden, epidemiology, and quality of life. Stroke Res Treat. 2018; 2018: 3238165 .

[3] National Institute of Neurological Disorders and Stroke rt-PA Stroke Study Group. Tissue plasminogen activator for acute ischemic stroke. N Engl J Med. 1995; 333: 1581-1587.

[4] Hacke W, Kaste M, Bluhmki E, et al. Thrombolysis with alteplase 3 to 4,5 hours after acute ischemic stroke. N Engl J Med. 2008; 359: 1317-1329.

[5] Wahlgren N, Ahmed N, Dávalos A, et al. Thrombolysis with alteplase 3-4,5 h after acute ischaemic stroke (SITS-ISTR): an observational study. Lancet 2008; 372: 1303-1309.

[6] Sandercock P, Wardlaw JM, Lindley RI, et al. The benefits and harms of intravenous thrombolysis with recombinant tissue plasminogen activator within $6 \mathrm{~h}$ of acute ischaemic stroke (the third international stroke trial [IST-3]): a randomised controlled trial. Lancet 2012; 379: 2352-2363. [Erratum: Lancet 2012; 380: 730.]

[7] Berkhemer OA, Fransen PS, Beumer D, et al. A randomized trial of intraarterial treatment for acute ischemic stroke. N Engl J Med. 2015; 372: 11-20.

[8] Goyal M, Demchuk AM, Menon BK, et al. Randomized assessment of rapid endovascular treatment of ischemic stroke. N Engl J Med. 2015; 372: 1019-1030.

[9] Snelling B, Mccarthy DJ, Chen S, et al. Extended window for stroke thrombectomy. J NeuroSci Rural Pract. 2019, 10: 294300.

[10] Saver JL, Goyal M, Bonafe A, et al. Stent-retriever thrombectomy after intravenous t-PA vs. $\mathrm{t}-\mathrm{PA}$ alone in stroke. $\mathrm{N}$ Engl J Med. 2015 ; 372: 2285-2295.
[11] Campbell BC, Mitchell PJ, Kleinig TJ, et al. Endovascular thera py for ischemic stroke with perfusion-imaging selection. $\mathrm{N}$ Engl J Med. 2015; 372: 1009-1018.

[12] Jovin TG, Chamorro A, Cobo E, et al. Thrombectomy within 8 hours after symptom onset in ischemic stroke. N Engl J Med. 2015; 372: 2296-2306.

[13] Davis S, Donnan GA. Time is penumbra: Imaging, selection and outcome. The Johann Jacob Wepfer Award 2014. Cerebrovasc Dis. $2014 ; 38$ : 59-72.

[14] Albers GW, Marks MP, Kemp S, et al. Thrombectomy for stroke at 6 to 16 hours with selection by perfusion imaging. $\mathrm{N} \mathrm{Engl} \mathrm{J}$ Med. 2018; 378: 708-718.

[15] Nogueira RG, Jadhav AP, Haussen DC, et al. Thrombectomy 6 to 24 hours after stroke with a mismatch between deficit and infarct. N Engl J Med. 2018; 378: 11-21.

[16] Thomalla G, Simonsen CZ, Boutitie F, et al. MRI-guided thrombolysis for stroke with unknown time of onset. N Engl J Med. 2018; 379: 611-622.

[17] Campbell BC, Ma H, Ringleb PA, et al. Extending thrombolysis to $4.5-9 \mathrm{~h}$ and wake-up stroke using perfusion imaging: a systematic review and meta-analysis of individual patient data. Lancet 2019; 394: 139-147. [Erratum: Lancet 2020; 395: 1906.]

[18] Pexman JH, Barber PA, Hill MD, et al. Use of the Alberta Stroke Program Early CT Score (ASPECTS) for assessing CT scans in patients with acute stroke. Am J Neuroradiol. 2001; 22: 15341542 .

[19] Tan IY, Demchuk AM, Hopyan J, et al. CT angiography clot burden score and collateral score: correlation with clinical and radiologic outcomes in acute middle cerebral artery infarct. Am J Neuroradiol. 2009; 30: 525-531.

[20] Nicholson P, Hilditch CA, Neuhaus A, et al. Per-region interobserver agreement of Alberta Stroke Program Early CT Scores (ASPECTS). J Neurointerv Surg. 2020; 11: 1069-1071.

[21] Kobkitsuksakul C, Tritanon O, Suraratdecha V. Interobserver agreement between senior radiology resident, neuroradiology fellow, and experienced neuroradiologist in the rating of Alberta Stroke Program Early Computed Tomography Score (ASPECTS). Diagn Interv Radiol. 2018; 24: 104-107.

[22] Urbach H, Kellner E, Egger K. Acute stroke imaging in the era of the DAWN, DEFUSE 3 and WAKE-UP study findings. Eur Neurol Rev. 2019; 14: 24-27.

[23] Lynn LA. Artificial intelligence systems for complex decisionmaking in acute care medicine: a review. Patient Saf Surg. 2019; 13: 6 .

[24] Nagaratnam K, Harston G, Flossmann E, et al. Innovative use of artificial intelligence and digital communication in acute stroke pathway in response to COVID-19. Future Healthe J. 2020; 7 : 169-173.

[25] Brinjikji W, Benson J, Campeau N, et al. Brainomix aspects software improves interobserver agreement and accuracy of neurologist and neuroradiologists in interpretation of aspects score and outperforms human readers in prediction of final infarct. J Neurointerv Surg. 2020; 12: Al12-Al13.

[26] Grunwald IQ, Kulikovski J, Reith W, et al. Collateral automation for triage in stroke: Evaluating automated scoring of collaterals in acute stroke on computed tomography scans. Cerebrovasc Dis. $2019 ; 47: 217-222$

(Bogner Péter dr., Pécs, Ifjúság útja 13., 7624 e-mail: bogner.peter@pte.hu)

A cikk a Creative Commons Attribution 4.0 International License (https://creativecommons.org/licenses/by/4.0/) feltételei szerint publikált Open Access közlemény, melynek szellemében a cikk bármilyen médiumban szabadon felhasználható, megosztható és újraközölhetö, feltéve, hogy az eredeti szerző és a közlés helye, illetve a CC License linkje és az esetlegesen végrehajtott módosítások feltüntetésre kerülnek. (SID_1) 